\title{
Isolation and Identification of Antagonistic Bacterium against Pathogens of Bacterial Tuber Rot of Amorphophallus muelleri
}

\author{
Nurfitri Arfani ${ }^{1}$, Rodiyati Azrianingsih ${ }^{2 *}$, Suharjono ${ }^{2}$ \\ ${ }^{1}$ Master Profram of Biology, Faculty of Mathematics and Natural Sciences, University of Brawijaya, Malang, Indonesia \\ 2Departemant of Biology, Faculty of Mathematics and Natural Sciences, University of Brawijaya, Malang, Indonesia
}

\section{Abstract}

Rhizosphere bacteria have the ability to protect the host plants from the infection of pathogenic microorganisms. This study aimed to identify rhizosphere bacteria that were capable of inhibiting the growth of bacterial isolates that cause tuber rot of Amorphophallus muelleri. Rhizosphere bacteria were isolated using Nutrient Agar medium by pour plate method. Isolates were subjected to antagonistic assay against several bacterial isolates from the rotten tuber of $A$. muelleri using dual culture method. The potential isolate was identified based on 16S rDNA sequence. Isolate R7 showed the strongest inhibition to the growth of bacterial isolates from rotten tuber with an inhibition zone diameter of $19.66 \mathrm{~mm}$. The 16S rDNA sequence of isolate R7 R7 was $99.7 \%$ similar to Delftia tsuruhatensis PCL1755. The isolate was potential to be developed as phytopathogen control agent.

Keywords: Amorphophallus, antagonistic bacteria, rhizosphere bacteria, rotten tuber, 16S rDNA.

\section{INTRODUCTION}

Tubers of Amorphophallus muelleri Blume. contain a high concentration of glucomannan. Glucomannan is a starch that can be used as a thickener agent in foods such as noodles [1]. Glucomannan in $A$. muelleri tubers has a high economic value and is expected to improve Indonesian economy. Therefore, it is necessary to increase the production of $A$. muelleri tuber. Nowadays, the problem is pathogenic microorganisms that attack the tubers either under the ground or even post-harvest. The common pathogenic microorganisms that attack the tubers are Erwinia caratovora and Pectobacterium caratovora on Amorphophallus konjac tuber [2,3] and Dickeya dadantii on Amorphophallus rivieri $[4,5]$.

To control the tuber rotting, farmers use chemicals such as pesticides. Continuous application of synthetic pesticides caused negative impacts on the environment [6]. The residue of the pesticides in the soil as well as on the plant parts (fruits, leaves, and tubers) $[7,8]$ were indirectly or directly toxic to humans $[9,10]$.

Therefore, biological agents are required as antagonistic agents to control the growth of bacterial rot pathogens. One alternative that can

\footnotetext{
Correspondence address: Rodiyati Azrianingsih

Email : rodiyati@ub.ac.id

Address : Dept. Biology, Faculty of Mathematics and Natural Science, University of Brawijaya, Veteran Malang, Malang 65145.
}

be used as an ecologically safe and effective antagonistic agent against pathogens is the rhizosphere bacteria [11,12,13]. Rhizosphere bacteria are present in the soil around plant roots. They have many benefits for plants such as promoting nitrogen fixation, phosphate and potassium solubilization, production of phytohormones and antibiotics $[14,15,16]$.

Some rhizosphere bacteria that act as antagonistic agents are Bacillus, Pseudomonas, Pantoea, and Lactobacillus. One of the antagonistic bacteria that can inhibit the growth of $E$. caratovora (one of the causes of tuber rot bacteria) is Bacillus subtilus. It is able to produce antibiotic compounds such as bacitracin, bacillin, bacillomycin B, difficidin, oxydifficidin, lecithinase, and subtilisin. These compounds cause shrink in cells so that bacterial cells of $E$. carotovora will lose water and experience plasmolysis $[17,18]$. In addition, Bacillus amyloliquefaciens is also able to inhibit the growth of Erwinia bacteria which causes postharvest tuber rot [19]. This research aims to analyze the potency of isolated rhizosphere bacteria to inhibit $A$. muelleri tuber rot bacteria and to identify the potential rhizosphere bacteria based on 16S rDNA sequence.

\section{MATERIAL AND METHOD Isolation of Rhizosphere Bacteria}

Soil samples were obtained from the rhizosphere of $A$. muelleri from Rejosari Village, Bantur City, East Java Province, Indonesia. The soil was taken at a depth of $5-10 \mathrm{~cm}$ of topsoil and kept in plastic bags in the isotherm box [20]. At each sampling point, abiotic factors including 
the ambient and soil temperature, and light intensity were measured directly at the field; while moisture, $\mathrm{pH}$, and organic matter of soil were measured in the Laboratory of Microbiology and Laboratory of Ecology, University of Brawijaya. The data of abiotic factors were analyzed using ANOVA and Tukey test with five percent significant differences.

Twenty five grams soil sample was diluted at $10^{-1}-10^{-7}$ in sterile physiological saline solution. Each suspension of $0.1 \mathrm{~mL}$ was transferred into Nutrient Agar (NA) medium in the Petri dishes according to pour plate method and incubated at room temperature for 72 hours. Each bacterial colony was enumerated and purified according to the spread plate method. The pure culture of rhizosphere bacteria in the NA medium was stored at $4^{\circ} \mathrm{C}$ [21]. The diversity of bacterial communities was determined based on the Simpson Diversity index according to the equation 1 [22-25].

$\mathrm{D}=1-\left\{\sum \mathrm{n}(\mathrm{n}-1) / \mathrm{N}(\mathrm{N}-1)\right\}$

Description:

$\mathrm{D}=$ Simpson Diversity Index

$\mathrm{n}=$ Number of individual types of $\mathrm{i}$

$\mathrm{N}=$ Total number of individuals

\section{Isolation of Pathogenic Bacteria from Rotten} Tuber of $A$. muelleri

Bacterial pathogens of $A$. muelleri tubers were isolated according to Ashmawy et al. [26] with modifications. The rotten of tuber was cut into a dimension of $1.0 \times 0.5 \times 0.2 \mathrm{~cm}^{3}$. It was sterilized by soaking in $1.0 \% \mathrm{NaOCl}$ solution for two minutes and rinsed two times with sterile $\mathrm{ddH}_{2} \mathrm{O}$. The pieces of sterilized rotten tuber were weighed to $25 \mathrm{~g}$. They were blended with $225 \mathrm{~mL}$ sterile physiological saline solution and diluted at $10^{-1}-10^{-7}$. Sample suspension of $0.1 \mathrm{~mL}$ was inoculated into NA medium according to pour plate method and incubated at room temperature for 48 hours. The bacterial colony was purified according to the spread plate method and pure cultures were stored at $4^{\circ} \mathrm{C}$.

\footnotetext{
Antagonist Assay of Rhizosphere Bacteria Against A. muelleri Tuber Rot Bacteria

The antagonistic assay among bacterial isolates was done using dual culture method [27]. The $100 \mu \mathrm{L}$ suspension of isolated tuber rot bacterium with $10^{6}$ cells. $\mathrm{mL}^{-1}$ density was spread on NA medium and directly incubated at $4^{\circ} \mathrm{C}$ for 4 hours. The NA agar plates were perforated to make $6 \mathrm{~mm}$ wells. The wells were inoculated with $60 \mu \mathrm{L}$ of $10^{7}$ cells. $\mathrm{mL}^{-1}$ density of antagonistic
}

rhizosphere bacteria. The cultures were incubated at room temperature for 72 hours. The growth inhibition of tuber rot bacteria was indicated by the clear zone around the well. The diameter of the inhibition zone were measured and the data was analyzed using ANOVA and Tukey test with five percent significant differences.

\section{Identification of Potential Rhizosphere Bacteria}

Rhizosphere bacteria with the highest potency to inhibit tuber rot bacteria was identified based on phenotypic and phylogenetic characters. Phenotypes of bacteria were characterized based on Bergey's Manual of Systematic Bacteriology $[28,29]$. The phenotype of bacteria consists of the colony and cell morphology, biochemical, and physiological characters. Phylogenetically, the bacteria isolate was identified based on 16S rDNA sequence similarity. The genomic DNA of the selected isolate was extracted using Heat Treatment method [30]. The sequence of 165 rDNA was amplified using universal primer of:

\section{$27 f$ (5'-AGAGTTTGATCCTGGCTCAG-3'), and 1492r (5' CTACGGCTACCTTGTTACGA-3')}

The composition of $50 \mu \mathrm{L}$ PCR reaction was 25 $\mu \mathrm{L}$ PCR master mix, $19 \mu \mathrm{L} \mathrm{ddH}_{2} \mathrm{O}, 2 \mu \mathrm{L}$ of each primer, and $2 \mu \mathrm{L}$ of DNA template. The components were homogenized and 16S rDNA was amplified using the PCR program at 35 cycles includes: predenaturation at $94^{\circ} \mathrm{C}$ for $5 \mathrm{~min}$, denaturation at $94^{\circ} \mathrm{C}$ for $30 \mathrm{~s}$, annealing at $55^{\circ} \mathrm{C}$ for $30 \mathrm{~s}$, and extension at $72^{\circ} \mathrm{C}$ for $90 \mathrm{~s}$; and followed by post extension at $72^{\circ} \mathrm{C}$ for 5 minutes.

The amplicon of $16 \mathrm{~S}$ rDNA was verified with electrophoresis on $1.5 \%$ agarose gel. The amplicon of $16 \mathrm{~S}$ rDNA was purified and sequenced at First Base, Malaysia using Automatic Sequencer Analyzer ABI 3130. The sequence of $16 \mathrm{~S}$ rDNA was edited using the Sequence Scanner V.1 program and the sequences were combined using the BioEdit V.7.2.5 program. The 16S rDNA sequence of the isolated bacteria was aligned together with $16 \mathrm{~S}$ rDNA reference that obtained from the NCBI database. The phylogenetic tree was constructed based on Neighbor-Joining with bootstrap 1000 using the MEGA 6.00 program [31,32,30].

\section{RESULT AND DISCUSSION \\ Density and Diversity of $A$. muelleri Rhizosphere Bacteria}

A total of isolates of $A$. muelleri rhizosphere bacteria were obtained from three locations. 
Based on Simpson's diversity index, community diversity of the rhizosphere bacteria was in the range of $0.84-0.87$ (Fig. 1). It indicated that the community was highly diverse and there were no dominant species [25]. However, the density of rhizosphere bacteria was relatively low in the range of 3.54 - 3.56 Log $10 \mathrm{CFU}^{-g^{-1}}(30.0-59.0 \mathrm{x}$ $10^{2}$ CFU.g ${ }^{-1}$ soil (Fig. 2). The low density might be caused by the low organic matter and low moisture of the soil. Since those parameters are limiting factors for the growth of several rhizosphere bacteria. Soil bacteria require a minimum of $2 \%$ soil organic matter and $60 \%$ soil moisture for support of the optimal growth $[33,34]$, while in this experiment the organic matter and soil were less than 0.2 and $32 \%$, respectively.

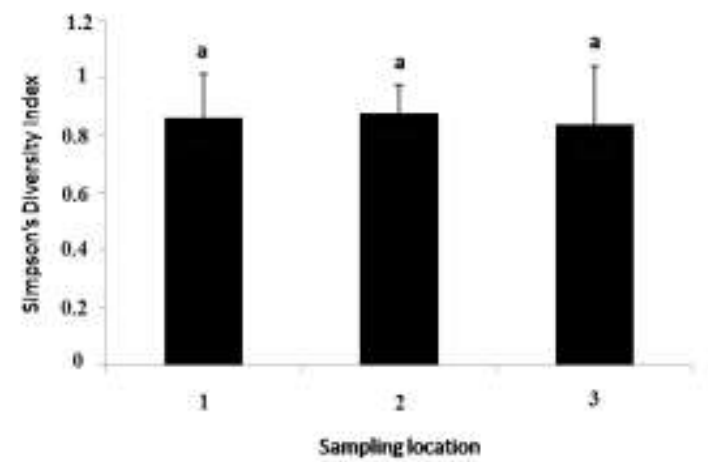

Figure 1. The Bacterial Diversity at rhizoSphere of $A$. muelleri Plantation. The same notation show diversity index does not significantly different among the sampling location ( $p>0.05)$.

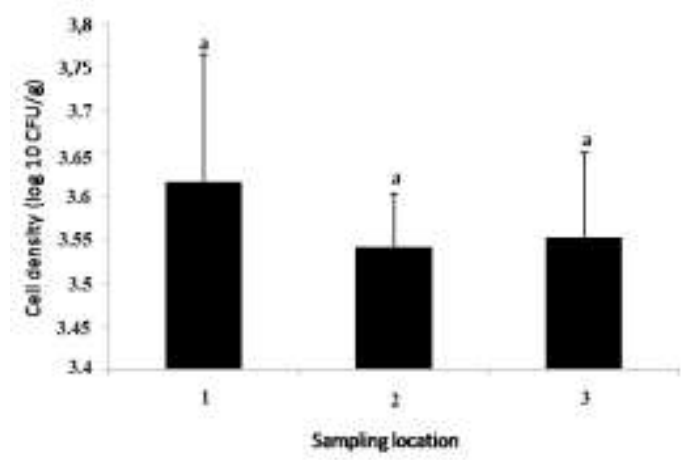

Figure 2. The Bacterial Density at Rhizosphere of $A$. muelleri Plantation. The same notation show cell density does not significantly different among the sampling location ( $p>0.05$ )

Environmental for the three sampling locations were presented in Table 1 . The soil parameters especially plant and soil type, and farm practice affects the diversity and density of soil microorganisms and plants growth [34]. The low nutrient and water availability in the soil may inhibit metabolism and growth of micro- organisms. Soil organic matter plays an important role in soil structure and texture, microaggregate stability, soil moisture and $\mathrm{pH}$, nutrient availability, and microorganism density and diversity $[25,35]$. In all locations, soil moisture was low due to low content of organic matter. Organic matter will increase soil moisture and decrease soil $\mathrm{pH}$. The increase of soil organic matter will increase the content of organic carbon which utilized by bacteria as carbon and energy source [36]. Soils of $A$. muelleri plantation were acid, with $\mathrm{pH}$ value $3.78-4.13$. In general, bacteria grow in the $\mathrm{pH}$ range 5-7 as optimum conditions [37]. The acidity of the soil may be caused by contamination of metals derived from the use of chemicals (fungicides and pesticides), pollution, organic fertilizers, and household waste disposal [38].

\begin{tabular}{lccc}
\multicolumn{3}{c}{ Table 1. Enviromental Parameters at Sampling Locations } \\
\hline \multicolumn{1}{c}{ Parameter } & Location 1 & Location 2 & Location 3 \\
\hline $\begin{array}{l}\text { Soil pH } \\
\begin{array}{l}\text { Soil Humidity } \\
\text { (\%) }\end{array}\end{array}$ & $4.13 \pm 0.12$ & $3.79 \pm 0.03$ & $4.01 \pm 0.01$ \\
$\begin{array}{l}\text { Soil organic } \\
\text { matter (\%) }\end{array}$ & $0.16 \pm 0.02$ & $0.17 \pm 0.03$ & $0.16 \pm 0.02$ \\
\hline
\end{tabular}

Antagonistic Potency of Rhizosphere bacteria

Rhizosphere bacteria consisting of nine isolates with a density of $10^{7} \mathrm{CFU} \cdot \mathrm{mL}^{-1}$ were tested for their inhibition against three tuber rot bacteria of $A$. muelleri (PT4, PL9, and PR11). The rhizosphere bacterial isolates had different potency in inhibiting and only four isolates can inhibit tuber rot bacteria (Fig. 3). Isolate R3 was not able to inhibit isolate PT4 but it inhibited isolate PL9 and PR11 with inhibition zone diameter 12 and $10 \mathrm{~mm}$, respectively. Isolate R5 was able to inhibit PT4, PL9, and PR11 with inhibition zone diameter of 2.07, 5.93, and 6.96 $\mathrm{mm}$ respectively. Isolate $\mathrm{R} 7$ was able to inhibit the three isolates of tuber rot bacteria, PT4, PL9, and PR11 isolate with inhibition zone diameter of 19.66, 11.24, and $12.42 \mathrm{~mm}$. Isolate R9 was only able to inhibit isolate PT4 and PL9 with inhibition zone diameter of 2.00 and $6.21 \mathrm{~mm}$, respectively.

Isolate R7 had the highest inhibition potency among the other $A$. muelleri rhizosphere bacteria. The isolate was able to inhibit the three isolates of tuber rot bacteria and categorized in the high potential with inhibition zone more than $>10 \mathrm{~mm}$ [39]. Based on previous experiment [40], Bacillus circulans rhizosphere bacterium was able to inhibit Escherichia coli, Bacillus subtilis, and Serratia marcescens with inhibition zone diameter of 11, 12, and $6 \mathrm{~mm}$, respectively. 
Antagonistic bacteria have a mechanism to inhibit the growth of pathogens. The inhibition is performed by producing antimicrobial compounds such as enzymes capable of attacking the main cell components of pathogens [41,42]. Antimicrobial compounds produced by antagonistic bacteria cause damage to the cell membrane and shrink the cell. Furthermore, the activity of the bacteria becomes disturbed and causes it to die. Another antibiotics compounds are responsible for inhibition of protein synthesis process. The synthesis is inhibited when exposed to antibiotic compounds and cause cell death of pathogens $[43,44]$.

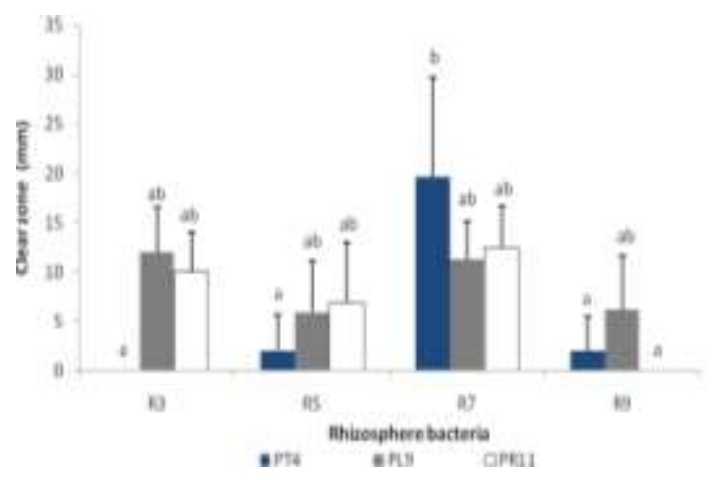

Figure 3. The Potency of $A$. muelleri Rhizosphere Bacteria to inhibit tuber rot bacteria (PT4. PL9, and PR11). The same notation show diversity index does not significantly different among the sampling location $(p>0.05)$

The inhibition mechanism of tuber rot bacteria by isolate R7 was antibiosis. Antibiosis is the ability of antagonistic isolates to produce secondary metabolites of antibiotics, siderophores, and several enzymes such as chitinase, protease, and cellulase enzymes that inhibit the growth of target cell $[45,46]$. The activity of antibiosis was determined by clear zones; it proved that rhizosphere bacteria could produce antibiotics that inhibited the growth of tuber rot bacteria $[47,48]$. In addition, inhibition potency of antagonistic bacteria may also be caused by antagonism such as competition of root colonization and nutrient [49-52]. Antagonism is the ability of antagonistic microorganisms to produce antibiotics that can kill pathogenic microorganisms [53]. Competition of space and nutrients cause limitation of nutrition and space for growth of pathogens [37,54,55,56].

Identification of $A$. muelleri Rhizosphere Bacterium as Antagonist of Tuber Rot Bacteria

The isolate R7 (Fig. 4) had a 99.7\% similarity of $16 \mathrm{~S}$ rDNA sequence with Delftia tsuruhatensis
PCL1755. The phenetypic data of isolate R7 was used as additional data to support the results of phylogenetic identification (Table 2). The strain is isolated from various soil types such as eggplant, tomato, pepper, and avocado and it showed a widespread inhibition to the growth of Fusarium oxysporum $f$. sp. radicis lycopersici $[57,58]$.

The $D$. tsuruhatensis is one of the rhizosphere bacteria that act as a biocontrol agent or plant growth promoting rhizobacteria (PGPR) [59]. Some strains of these bacteria have the ability to degrade the inorganic pollutants [60]. The natural habitat of these bacteria are dispersed in soil, activated sludge, and also in contaminated environments. Bacteria $D$. tsuruhatensis was first isolated from active sludge and acted as degradation of terephthalate or plastic (environmental pollutants) [57,58,61]. One strain of Delftia is D. tsuruhatensis HR4 had the ability to control disease in rice caused by Xanthomonas oryzae, Rhizoctonia solani, and Pyricularia oryzae $[60,62,63]$. In some studies, although it has the ability as an antagonist agent against pathogens, the mechanisms of synthesis and antimicrobial compounds owned by these bacteria is still unclear. This is due to the lack of research on these bacteria. The strain of $D$. tsuruhatensis MTQ3 has the ability to inhibit the growth of Ralstonia solancearum and Phytophtohora nicotinae [58].

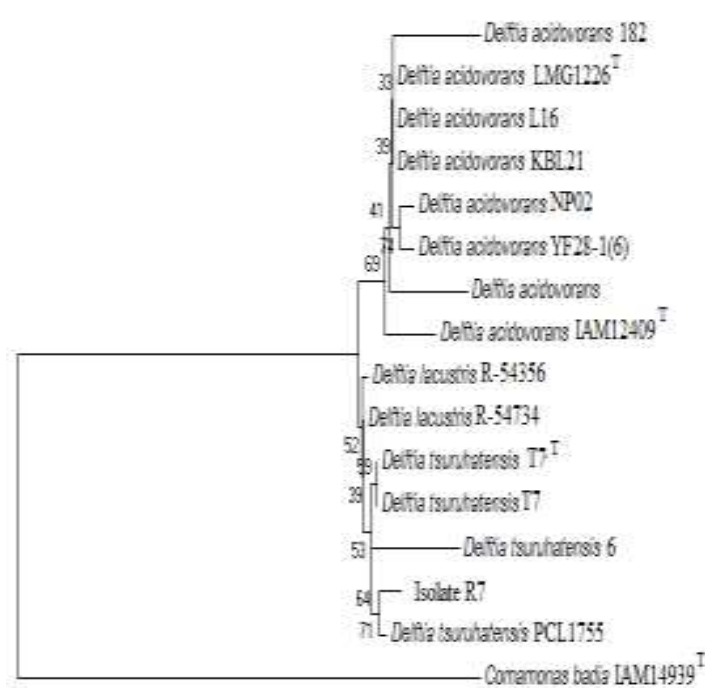

[II

Figure 4. Phylogeny Tree of Rhizosphere Bacteria and Reference Isolates Based on 16S rDNA Sequence according to Neighbor-Joining Algorithm 
Table 2. Phenotypic Characteristics of Rhizosphere Bacterium Isolate R7

\begin{tabular}{lc}
\hline \multicolumn{1}{c}{ Characteristics of phenotypes } & Isolate R7 \\
\hline Colony & Irregular \\
Shape & Convex \\
Colony Elevation & Wave \\
Configuration & Smooth \\
Texture & Like butter \\
Consistency & Cream \\
Colors & \\
\hline Cell & Negative \\
Gram staining & Rod \\
Cell Shape & Negative \\
Catalase & Positive \\
Nitrate Reduction & Positive \\
Simmon Sitrat & Negative \\
Methyl Red Test (MR) & Negative \\
Voges Proskauer Test & \\
Sugar fermentation & Positive \\
- Glucose & Positive \\
- Sucrose & Negative \\
- Lactose & Negative \\
- Mannitol & Positive \\
- Maltose & \\
Ability to live in salinity & Positive \\
- 0\% & Positive \\
- 5\% & Negative \\
- 10\% & Positive \\
Aerobic growth &
\end{tabular}

\section{CONCLUSION}

The rhizosphere bacteria isolate $\mathrm{R} 7$ of $A$. muelleri had the highest potency as antagonist of tuber rot bacteria. The isolate $\mathrm{R} 7$ had $99.7 \%$ similarity with Delftia tsuruhatensis PCL1755 base on $16 \mathrm{~S}$ rDNA sequence. This isolate is potential to be developed as biological control/biopesticide agent against tuber rot bacteria of $A$. muelleri.

\section{REFERENCES}

[1] Rahmawati, N. Y. N, A. Daroini. 2014. Strategi pengembangan komoditi tanaman Porang (Amorphophallus onchophyllus) di Kabupaten Nganjuk. Jurnal Manajemen dan Agribisnis. 14(1). 51-56.

[2] Wu, J.P., Y. Diao, Y. Gu, Z. Hu. 2011. Molecular detection of Pectobacterium species causing soft rot of Amorphophallus konjac. World J. Microbiol. Biotechnol. 27(3). 613-618.

[3] Zhang, L.H., L. Liao, Y.J. Wang, G.H. Ji. 2011. Biocontrol effect of Lysobacter antibioticus 06-4 on soft rot pathogen of Amorphophallus konjac its mechanism. J. Hunan Agricultural Univ. (Nat. Sci.). 37. 286289.

[4] Czajkowski, R., M.C.M. Perombelon, J.A. van Veen, J.M. van der Wolf. 2011. Control of blackleg and tuber soft rot of potato caused by Pectobacterium and Dickeya species: a review. Plant Pathol. Microbiol. 60(6). 9991013.

[5] Toth, I.K., V.D. Wolf, J.M. Saddler, G. Lojkowska, E. Helias, V. Pirhonen, M. Tsror, J.G. Elphinstone. 2011. Dickeya species: an emerging problem for potato production in Europe. Plant Pathol. 60(3). 385-399.

[6] Taufiq, E., H.B.P. Soekarno, M. Surahman. 2017. Keefektifan Trichoderma sp. dan Fusarium non patogenik dalam mengendalikan penyakit busuk pucuk vanili berwawasan lingkungan. Jurnal Littri. 23(1). 18-25.

[7] Djojosumarto, P. 2000. Teknik aplikasi pestisida pertanian. Kanisius. Yogyakarta.

[8] Wudianto, R. 2010. Petunjuk penggunaan pestisida. Penebar Swadaya. Jakarta.

[9] Djojosumarto, P. 2008. Pestisida dan aplikasinya. Agro Media Pustaka. Jakarta.

[10] Mukono. 2010. Toksikologi lingkungan. Airlangga University Press. Surabaya.

[11] Anith, K.N., N.V. Radhakrishnan, T.P. Manomohandas. 2003. Screening of antagonistic bacteria for biological control of nursery wilt of Black Pepper (Piper nigrum). Microbiol. Res. 158. 91-97.

[12] Agustiyani, D., A. Nditasari, N. Laili, S. Antonius. 2014. Penapisan dan identifikasi bakteri agens biokontrol penyakit layu fusarium hasil isolasi dari rhizosfer pisang. Jurnal Fitopatologi Indonesia. 10(1). 23-30.

[13] Zhou, Q.X., Y.Y. Chen, Y.L. Yang, S.E. Strelkov. Effect of inoculum density and quantitative PCR-based detection of Rhizoctonia solani AG-2-1 and Fusarium avenaceum on canola. Crop Protection. 59. 7-71.

[14] Dela, P.C., V.M. Loyola. 2014. Biotic interactions in the rhizosphere: a diverse cooperative enterprise for plant productivity. Plant Physiol. 166(2). 701-719.

[15] Dasgupta, D., D. Dasgupta, A. Ghati, A. Sarkar, C. Sengupta, G. Paul. 2015. Application of plant growth promoting rhizobacteria (PGPR) isolated from the rhizosphere of Sesbania bispinosa on the growth of chickpea (Cicer arietinum L.). Int. J. Curr. Microbiol. Appl. Sci. 4(5). 1033-1042.

[16] Vejan, P., R. Abdullah, T. Khadiran, S. Ismailand, A.N. Boyce. 2016. Role of plant growth promoting rhizobacteria in agricultural sustainability: a review. Molecules. 21(573). 1-17. 
[17] Sharga, BM., G.D. Lyon. 1998. Bacillus subtilis BS 107 as an antagonist of potato blackleg and soft rot bacteria. Can. J. Microbiol. 44(8). 83-777.

[18] Javandira, C., L.Q. Aini, A.A. Abadi. 2013. Pengendalian penyakit busuk lunak umbi kentang (Erwinia caratovora) dengan memanfaatkan agen hayati Bacillus subtilis dan Pseudomonas flourescens. Jurnal Hama dan Penyakit Tanaman. 1(1). 90-97.

[19] Zhao, Y., P. Li, K. Huang, Y. Wang, H. Hu, Y. Sun. 2013. Control of postharvest soft rot caused by Erwinia carotovora of vegetables by a strain of Bacillus amyloliquefaciens and its potential modes of action. World J. Microbiol. Biotechnol. 29(3). 411-420.

[20] Szymanska, S., T. Plociniczak, Z.P. Seget, M. Zloch, S. Ruppel, K. Hrynkiewicz. 2016. Metabolic potential and community structure of endophytic and rhizosphere bacteria associated with the roots of the halophyte Aster tripolium L. Microbiol. Res. 182. 68-79.

[21] Keusalya, H., Baharuddin, B. Zakaria, S.A. Syaiful. 2015. Isolation and physiological characterization of PGPR from potato plant rhizosphere in medium land of Buru Island. Procedia Food Sci. 3. 190-199.

[22] Ludwig, J.A., J.F. Reynolds. 1988. statistical ecoloqy a primer on methods and computing. John Wiley and Sons. New York.

[23] Wafula, E.N. 2013. Analyses of soil bacteria in Ngere Tea catchment area of Murang'a County, Kenya. Thesis. Jomo Kenyatta University of Agriculture and Technology.

[24] Susilowati, D.N., F. Fauziah, M.R. Setiawati, E. Pranoto, E. Hidayati, M. Setyowati, Y. Rachmiati. 2016. Analisis komunitas bakteri rhizosfer tanaman teh pada pembenihan menggunakan teknik Terminal Restriction Fragment Length Polymorphism (TRFLP). Jurnal Penelitian Teh dan Kina. 19(2). 147156.

[25] Chen, G.H., T.X. Liang, W.D. Dong, L. Jian, M Z. Chuan, Y.Y. Hong, X.B. Yan. 2017. Expression of mitogen activated protein kinase double stranded RNA in cucumber has no apparent effect on the diversity of rhizosphere Archaea. J. Integr. Agr. 16(10). 2239-2245.

[26] Ashmawy, A., N.M. Jadalla, A.A. Shoeib, A. El-Bebany. 2015. Identification and genetic characterization of Pectobacterium spp. and related Enterobacteriaceae causing potato soft rot disease in Egypt. J. Pure Appl. Microbiol. 9(3). 1847-1858.

[27] Awais, M., M. Tariq, A. Ali, Q. Ali, A. Khan, B. Tabassum, I.A. Nasir, T. Husnain. 2015. Isolation, characterization and inter relationship of phosphate solubilizing bacteria from the rhizosphere of sugarcane and rice. Biocatal. Agric. Biotechnol. 17. 132.

[28] Krieg, N.R., J.G. Holt. 1984. Bergye's manual of systematic bacteriology, Vol. 1. The Williams and Wilkins Co. Baltimore.

[29] Mayz, J., L. Manzi, A. Larez. 2013. Isolation, characterization and identification of hydrocarbonoclastic Pseudomonas Species inhabiting the rhizosphere of Crotalaria micans link. Eur. J. Exp. Biol. 3(5). 313-321.

[30] Bergkessel, M., G. Christine. 2013. Colony PCR. Department of Biochemistry and Biophysics, University of California. San Francisco, CA, USA.

[31] Naveed M., S. Mubeen, S. Khan, I.A.N. Khalid, H.A.R. Suleria, A. Bano, A.S. Mumtaz. 2014. Identification and characterization of rhizospheric microbial diversity by $16 \mathrm{~S}$ Ribosomal RNA gene sequencing. Braz. J. Microbiol. 45 (3). 985993.

[32] Mohkam, M., N. Nezafat, A. Berenjian, M. A. Mobasher, Y. Gashemi. 2016. Identification of Bacillus probiotics isolated from soil rhizosphere using $16 \mathrm{~S}$ rRNA, recA, $r p o B$ gene sequencing and RAPD-PCR. Probiotics Antimicrob. Protocol. 8. 8-18.

[33] Borowik, A., J. Wyszkowska. 2016. Soil moisture as a factor affecting the microbiological and biochemical activity of soil. Plant Soil Environ. 62(6). 250-255.

[34] Lutfiyana, N. Hudallah, A. Suryanto. 2017. Rancang bangun alat ukur suhu tanah, kelembaban tanah, dan resistansi. Jurnal Teknik Elektro. 9(2). 80-86.

[35] Garbeva, P., J.A. van Veen, J. D. van Elas. 2004. Microbial diversity in soil: selection of microbial population by plant and soil type and implications for disease suppressiveness. Annu. Rev. Phytopathol. (42). 243-270.

[36] Ladinthar, R., M.S. Dhakar. 2015. Relationship between soil bacteria population and various physic chemical properties at two broadleaved forest stand of Meghalaya differing in altitudes. Transcriptomics. 3(2). 125-131. 
[37] Darmiati, N.N., I.M. Sudarma 2017. Keragaman mikoflora tanah supresif dalam mengendalikan penyakit akar gada pada tanaman kubis (Brassica oleracea L.). Ecotrophica. 11(1). 70-75.

[38] Alghanmi, S.I., A.F. Al Sulami, T.A. El-Zayat, B.G. Alhogbi, M.A. Salam. 2015. Acid leaching of heavy metals from contaminated soil collected from Jeddah, Saudi Arabia: kinetic and thermodynamics studies. Int. Soil Water Conserv. Res. 3. 196208.

[39] Patkowska, E., M. Konopinski. 2014. Antagonistic bacteria in the soil after cover crops cultivation. Plant Soil Environ. 60(2). 69-73.

[40] Abada, N.A., H.H. El-Hendawy, M.E. Osman, M.A. Hafez. 2014. Antimicrobial activity of Bacillus circulans isolated from rhizosphere of Medicago sativa. Life Sci. J. 11(8). 711719.

[41] Agrios, G.N. 2005. Plant pathology, $5^{\text {th }}$ Ed. Elsevier. Academic Press, Oxford. UK.

[42] Jeyaseelan, E.C., S. Tharmila, K. Niranjan. 2012. Antagonistic activity of Trichoderma spp. and Bacillus spp. against Pythium aphanidermatum isolated from tomato damping off. Arch. Appl. Sci. Res. 4(4). 16231627.

[43] Olivera, F.C., R.C. Geruza, S.M. Amanda, A.S. Andre, B. Adriano. 2006. Bacteriocin like substance inhibits potato soft rot caused by Erwinia carotovora. Can. J. Microbiol. 52(6). 533-539.

[44] Diarta, I.M., C. Javandira, I.K. Widnyana. 2016. Antagonistik bakteri Pseudomonas spp. dan Bacillus spp. terhadap jamur Fusarium oxysporum penyebab penyakit layu tanaman tomat. Jurnal Bakti Saraswati. 5(1). 70-77

[45] Hallmann, J.A., Q. Hallmann, W.F. Mahaffee, J.W. Kloepper. 1997. Bacterial endophytes in agricultural crops. Can. J. Microbiol. 43. 895-914.

[46] Prihatiningsih, N., T. Arwiyanto, B. Hadisutrisno, J. Widada. 2015. Mekanisme antibiosis Bacillus subtilis B315 untuk pengendalian penyakit layu bakteri kentang. Jurnal Hama dan Penyakit Tumbuhan Tropika. 15(1). 64-71.

[47] Haggag, W.M, M. Haa. 2007. Biotechnological aspects of microorganism used in plant biological control. World $\mathrm{J}$. Agric. Sci. 3(6). 771-776.
[48] Lo, C.T. 1998. General mechanisms of action of microbial biocontrol agents. Plant Pathol. Bull. 7. 155-166.

[49] Baker, P.A., B.J. Duijff, G. Recobert, J.E. Loper, P. Lemanceau. 1999. Microbial antagonism at the root is involved in the suppression of Fusarium wilt by the combination of nonpathogenic Fusarium oxysporum Fo47 and Pseudomonas putida WCS358. Phytophathology. 89. 79-1073.

[50] Singh, D.P., H.B. Singh. 2008. Microbial wealth regulate crop quality and soil health. In: Knowledge Treasure on ELISA. Departement of Mycology and Plant Pathology, Institute of Agriculture Sciences. Baranas Hindu University. Varanasi, Uttar Pradesh.

[51] Junaid, J.M., D. Na, B. Ta, B. Ah, B. Ma. 2013. Commercial biocontrol agents and their mechanism of action in the management of plant pathogens. Int. J. Modern Plant Anim Sci. 1(2). 39-57.

[52] Kartini, E., A.L. Abadi, L.Q. Aini. 2014. Pengembangan Bio-bakterisida yang memanfaatkan bahan aktif bakteri endofit potensial antagonis untuk mengendalikan Erwinia sp. di umbi kentang. Jurnal Hama dan Penyakit Tumbuhan. 2(4). 63-70.

[53] Sakthivel, N., S.S. Gnanamanicham. 1987. Evaluation of Pseudomonas Fluorescens for suppression of sheath rot disease and for enhancement of grain yields in rice (Oryza sativa L.). Appl. Environ. Microbiol. 53(9). 2056-2059.

[54] McKellar, M.E., E.B. Nelson. 2003. Compost induced suppression of Pyhthium Damping off is mediated by fatty acid metabolizing seed colonizing mikrobial communities. Appl. Environ. Microbiol. 69(1). 452-460.

[55] Djatnika, I. 2012. Seleksi bakteri antagonis untuk mengendalikan layu Fusarium pada tanaman Phalaenopsis. Holticultural Plant Journal. 22(3). 276-284.

[56] Validov, S., F. Kamilova, S. Qi, D. Stephan, J.J. Wang, N. Makarova, B. Lugtenberg. 2007. Selection of bacteria able to control Fusarium oxysporum f. sp. radicis lycopersici in stonewool substrate. J. Appl. Microbiol. 102(2). 461-471.

[57] Hou, Q., C. Wang, H. Guo, Z. Xia, J. Ye, K. Liu, Y. Yang, X. Hou, H. Liu, J. Wang, B. Du, Y. Ding. 2015. Draft genome sequence of Delftia tsuruhatensis MTQ3, a strain of plant growth promoting rhizobacterium 
with antimicrobial activity. Genome Announc. 3(4). 5-12.

[58] Jin, F., Y. Ding, W. Ding , M.S. Reddy, W.G.D. Fernando, B. Du. 2011. Genetic diversity and phylogeny of antagonistic bacteria against Phytophthora nicotianae isolated from tobacco rhizosphere. Int. J. Mol. Sci. 12(5). 3055-3071.

[59] Gusseme, De, L. Vanhaecke, W. Verstraete, N. Boon. 2011. Degradation of acetaminophen by Delftia tsuruhatensis and Pseudomonas aeruginosa in a membrane bioreactor. Water Resistant. 45(4). 18291837.

[60] Shigematsu, T., K. Yumihara, Y. Ueda, M. Numaguchi, S. Morimura, K. Kida. 2003. Delftia tsuruhatensis sp. nov., a terephthalate assimilating bacterium isolated from activated sludge. Int. J. Syst. Evol. Microbiol. 53(5). 1479-1483.

[61] Han, J., L. Sun, X. Dong, Z. Cai, X. Sun, H. Yang, Y. Wang, W. Song. 2005. Characterization of a novel plant growthpromoting bacteria strain Delftia tsuruhatensis HR4 both as a diazotroph and a potential biocontrol agent against various plant pathogens. Syst. Appl. Microbiol. 28(1). 66-76.

[62] Ubalde, M.C., V. Brana, F. Sueiro, M.A.A. Morel, C.M.S. Rosales, C. Marquez, S.C. Sowinski. 2012. The versatility of Delftia sp. isolates as tools for bioremediation and biofertilization technologies. Curr. Microbiol. Appl. Sci. 64(6). 597-603.

[63] Morel, M.A., A. Iriarte, E. Jara, H. Musto, S. C. Sowinski. 2016. revealing the biotechnological potential of Delftia sp. JD2 by a genomic approach. Aims Bioengineering. 3(2). 156-175. 